\title{
Machines for non-chemical intra-row weed control in narrow and wide-row crops: a review
}

\author{
Andrea Peruzzi, Luisa Martelloni, Christian Frasconi, Marco Fontanelli, Michel Pirchio, \\ Michele Raffaelli
}

Department of Agriculture, Food and Environment, University of Pisa, Italy

\begin{abstract}
Intra-row weed control in organic or low-input cropping systems is more difficult than in conventional agriculture. The various mechanical and thermal devices available for intra-row weed control are reported in this review. Low-tech mechanical devices such as cultivators, finger-weeders, brush weeders, and torsionweeders tend to be used in low density crops, while spring-tine harrows are mainly applied in narrow-row high-density crops. Flame weeding can be used for both narrow and wide-row sown crops, provided that the crop is heat-tolerant. Robotic weeders are the most recent addition to agricultural engineering, and only a few are available on the market. Nowadays, robotic weeders are not yet used in small and medium sized farms. In Europe, highincome niche crops are often cultivated in small farms and farmers cannot invest in high-tech solutions. Irrespectively of the choice of low- or high-tech machines, there are several weeders that can be used to reduce the use of herbicides, making of them a judicious use, or decide to avoid them.
\end{abstract}

\section{Introduction}

The history of weed control in industrialised countries over

Correspondence: Andrea Peruzzi, Department of Agriculture, Food and Environment (DAFE), University of Pisa, via del Borghetto 80, 56124 Pisa, Italy.

Tel.: +39.050.2218942

E-mail: andrea.peruzzi@unipi.it

Key words: Agricultural engineering; cultivator; flamer; harrow; mechanical implement; non-chemical weed control; physical weed control; robotic weeding; thermal implement.

See online Appendix for additional Figures.

Received for publication: 18 July 2016.

Accepted for publication: 27 September 2016.

CCopyright A. Peruzzi et al., 2017

Licensee PAGEPress, Italy

Journal of Agricultural Engineering 2017; XLVIII:583

doi:10.4081/jae.2017.583

This article is distributed under the terms of the Creative Commons Attribution Noncommercial License (by-nc 4.0) which permits any noncommercial use, distribution, and reproduction in any medium, provided the original author(s) and source are credited. the past century highlights that simplicity and convenience are the criteria related to weed management decisions by growers (Shaner and Beckie, 2013). Over the last fifteen years, the environmental concerns and the impact of herbicide use on human health, the increase in weed populations worldwide resistant to herbicides with several modes of action, the scarce availability of active ingredients (a.i.) for minor crops such as vegetables, and the increase in organic farming have stimulated the development of new methods for non-chemical weed control (Harker and O'Donovan, 2013; Pannacci and Tei, 2014). In the European Union, the European Commission (EC) is promoting low pesticide-input farming in Member States and individual governments are expected to create the necessary conditions for farmers to implement physical weed control (Hillocks, 2012). Mechanical and thermal machines for weed control are physical means, which has traditionally been the pillar of non-chemical weed control (Shaner and Beckie, 2013). Both mechanical and thermal devices for weed control have become increasingly used due to the strict European Union legislation on chemical herbicides, and low availability of active ingredients registered for minor crops. In addition, they have benefits both in terms of impacts on environment and human health (Martelloni et al., 2016b).

Weeds need to be controlled during the critical period of weed control (CPWC) in order to prevent yield losses. The CPWC is the period of time between the maximum amount of time in which early-season weed competition can be tolerated by the crop before the crop suffers irrevocable yield reduction and the minimum weed-free period required from the time of planting to prevent yield reductions. This means that the CPWC is the interval in the life cycle of the crop in which it must be kept weed free to prevent unacceptable yield losses (Knezevic et al., 2002). The aim of weed control is to kill weeds or suppress them long enough for the crop to gain a competitive advantage. The optimum timing for physical weed control (both mechanical and thermal) is influenced by the competitive ability of the crop and the growth stage of the weeds (Bond and Grundy, 2001). The effectiveness of weeding is inversely related to the weed growth stage at the time of treatment. In the case of broadleaf weeds, the general recommendation for non-chemical weeding is to control plants that have only developed cotyledons and have produced up to 1-2 true leaves (Melander et al., 2005).

Weed management in organic or low-input growing systems entails integrating preventive and curative methods (Bàrberi, 2002). Preventive practices are needed for an effective long-term weed management in crop production systems (Gabe et al., 2014). Preventive methods such as crop rotation (Bond and Grundy, 2001), use of cover crops, fertiliser placement (Rasmussen, 2002), use of competitive species and varieties (Lemerle et al., 2001), planting methods (e.g., sod-seeding), tillage systems (e.g., minimum tillage), seedbed preparation, irrigation and drainage systems, and harvest weed seed control (Walsh et al., 2013) can keep 
weed populations at a manageable level within the growing system as a whole. On the other hand, pre- and post-emergence weed control during the CPWC is required to control weeds when thresholds are exceeded and could determine yields reductions.

Since ancient times tillage has played an important role in weed control and has been used as an effective management tool. Successfully managing weeds means that both primary and secondary tillage should limit weed emergence and prevent the formation of soil clods, as such clods impede post-emergence interventions with mechanical means (Peruzzi et al., 2011a, 2011b). One of the most useful techniques for non-chemical control systems is the false or stale seedbed technique, which entails preparing the seedbed at least 10-15 days before planting (sowing or transplanting) to let the weed seeds germinate and emerge. When the soil moisture is at a level to allow germination, subsequent flaming or harrowing will eliminate many of the seedlings. When the soil conditions and the time are favourable, this procedure can be repeated several times prior to the establishment of the crop (Rasmussen, 2004). In false seedbed technique the preparation of the seedbed is followed by one or more superficial secondary tillage with appropriate implements at about one-week intervals prior to sowing or transplanting the crop (Mohler, 2001). When soil conditions and time allow performing shallow soil tillage this procedure can be repeated several times prior to sowing or transplanting the crop (Cloutier et al., 2007). Implements like flex-tine harrows and rolling harrows can be properly used for this purpose (Peruzzi et al., 2011b). Pre-emergence soil cultivation after sowing and before crop emergence has the potential to control early germinating weeds. At the same time, it may cause problems by stimulating subsequent weed germination (Melander $e t$ al., 2005). The stale seedbed technique is realised almost in the same way of false seedbed technique, but it includes before transplanting or crop emergence the control of the emerged weeds without disturbing the soil (Mohler, 2001). Traditionally herbicides were utilised for this purpose, but in organic agriculture flaming can be properly used (Rasmussen, 2003).

Reliability of non-chemical means is usually more critical than that of herbicide-based weed management systems: all methods that prevent weed germination enhance crop competition and weeds must be directly controlled in order to obtain the best results (Rasmussen, 2004). Combining physical pre- and post-emergence weed control has a greater impact than the sole effect of the two methods separately (Melander, 1998; Melander and Rasmussen, 2001; Peruzzi et al., 2007; Ascard and Fogelberg, 2008; Raffaelli et al., 2010). The combined effect of the physical methods are not a result of synergistic interactions, but rather a sum of the effects of the two methods, which means that a certain amount of weeds can be controlled irrespectively of the preceding treatments (Melander and Rasmussen, 2001).

Pre-emergence mechanical weed control and flaming has no long-term effects and late emerging weeds still need to be controlled (Ascard and Fogelberg, 2008). In post-emergence of the crop, weeds that grow in the inter-row space can be easily controlled by using cultivators. However, weeds in the intra-row space of the crop are problematic and require the use of specific tools (Cloutier et al., 2007; van der Weide et al., 2008). The choice of such tools and how they are used depend on for example, the specific crop, weeds, farm, field and weather conditions (van der Schans et al., 2006).

This review focuses on the commercially available mechanical and thermal machines and devices - from easily accessible lowtech devices to high-tech robotic weeders - used worldwide for intra-row weed control.

\section{Weed control prior to crop emergence}

To avoid crop damage, intra-row weed control is best delayed until the crop plants are sufficiently developed, but at this time the weeds are usually too big to be controlled effectively. Intra-row weed control often needs to be conducted one or two weeks after crop emergence. Thus cultural practices and weed control prior to crop emergence (pre-emergence weed control) before crop emergence are critical in terms of maintaining weeds at a low density level in the early crop stages (Ascard and Fogelberg, 2008).

Pre-emergence harrowing can be used after the crop is sown, but before it emerges (Lundkvist, 2009) and can be conveniently applied in combination with false seedbed technique. Pre-emergence harrowing is usually gentle on the crop, provided that the crop is sown deeper in the soil than the soil layers from which most weed species emerge (van der Weide et al., 2008). Harrowing during the period between sowing and the emergence of crop seedlings is feasible only when germinating seeds of the crop are deeper than the cultivation depth (van der Schans et al., 2006). However, pre-emergence harrowing frequently stimulates new flushes of weed emergence, which can increase weed pressure after crop emergence. This is why flaming for pre-emergence weed control is advisable as the last treatment in the stale seedbed technique (Figure 1) (Peruzzi et al., 2007).

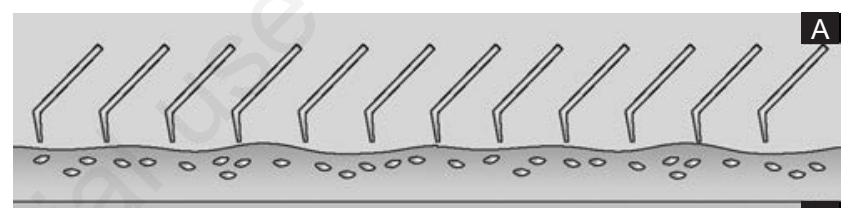

B
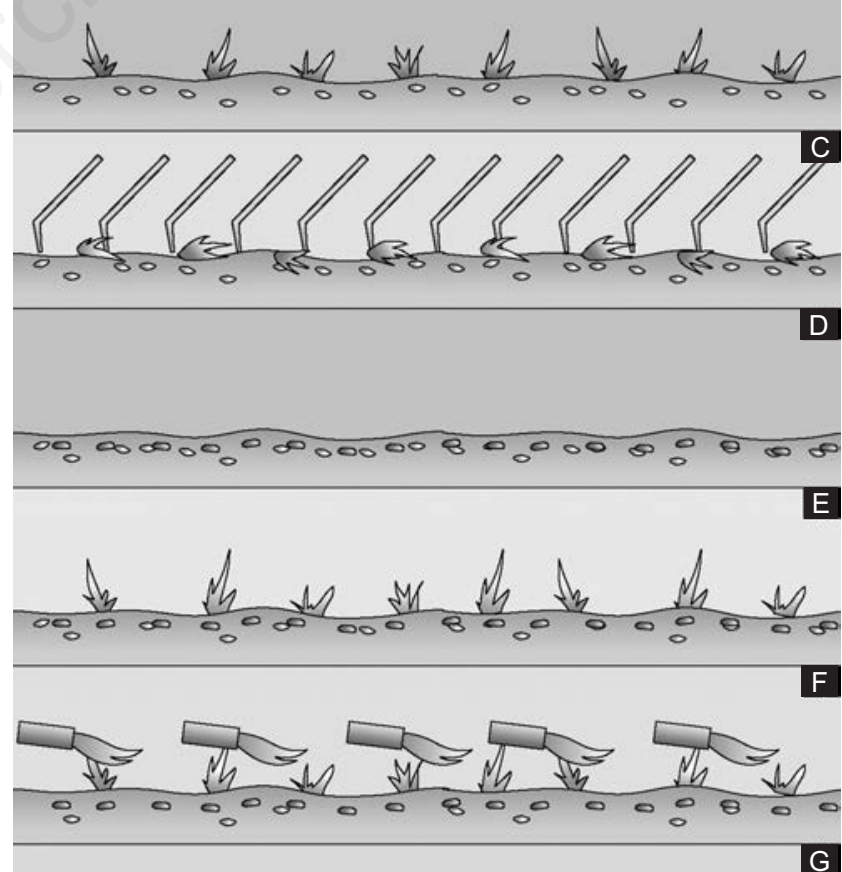

G

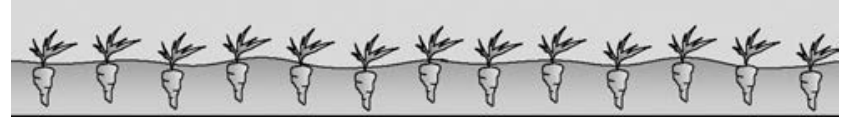

Figure 1. The stale seedbed technique conducted in carrot: A) first pass using spring-tine harrow; B) emergence of weeds; C) second pass using spring-tine harrow; D) carrot sowing; E) new weed emergence; F) pre-emergence flame weeding; G) carrot emergence (Peruzzi et al., 2007). 
Melander and Rasmussen (2001) found that pre-emergence flaming is a key factor for obtaining effective intra-row weed control also in later crop stages, and controls more weeds than pre-emergence harrowing. The dose of liquefied petroleum gas (LPG) used in flaming should be related to weed abundance, species, growth stage, and heat tolerance, and may range from very low rates $\left(20-30 \mathrm{~kg} \mathrm{ha}^{-1}\right)$ to high rates (90-100 kg ha ${ }^{-1}$ ) (Peruzzi and Raffaelli, 2000; Ascard and Fogelberg, 2008; Raffaelli et al., 2010, 2011; Fontanelli et al., 2015b; Martelloni et al., 2016a, 2016b).

\section{Preventive control of weed seeds by steaming in the intra-row space}

An effective weed control method for high-income low-competitive sown crops (e.g., carrot) can be obtained by using steaming to devitalise weed seeds in the intra-row space before the crop is sown. This gives a high competitive advantage to the crop in the CPWC (Raffaelli et al., 2016). Soil steaming kills most weed seeds, including dormant seeds (Bàrberi et al., 2009, Peruzzi et al., 2012). Soil steaming can reduce laborious intra-row hand weeding in row crop systems where herbicides are not used (Ascard and van der Weide, 2011). Mobile soil steaming machines ensure almost complete weed control for long periods. The older prototype steaming machines applied steam over the whole cultivated surface. Fennimore et al. (2014) used a mobile steam machine that mixed the steam with the soil as it passed through the shaped planting beds. They observed a decrease in time for hand weeding ranging from $25 \%$ to $93 \%$ in steamed raised beds (Fennimore et al., 2014). Nishimura et al. (2015) applied steam to non-woven bags placed on the soil, and found that seed mortality increased when the steaming machine was used at lower speeds, thus increasing the steam dose.

Peruzzi et al. (2011c) used a self-propelled machine for continuous broad steaming. The steamer (Celli Ecostar SC 600) was developed in cooperation with the University of Pisa and Celli (Celli SpA, Forlì, Italy). Schematically, the machine applies steam together with exothermic compounds, which are mixed with the soil while performing tillage with a blade rotor (Bioflash System ${ }^{\mathrm{TM}}$ ). As exothermic compound, calcium oxide $(\mathrm{CaO})$ is commonly used to provide extra heat to the soil.

Bàrberi et al. (2009) found that total seedling emergence after steam application was inversely related to $\mathrm{CaO}$ doses. Peruzzi et al. (2011c) found that the use of steaming along with an exothermic compound (in this case $\mathrm{KOH}$ ) applied before crop sowing resulted in weed suppression in terms of fresh biomass. Peruzzi et al. (2012) used an improved version of their previous machine (Peruzzi et al., 2011c) to test the effect of broad steaming on the natural weed seedbank. They found a weed emergence ranging from 0 to 360 plants $\mathrm{m}^{-2}$ when a steam dose of 2.5 $\mathrm{kg} \mathrm{m}^{-2}$ was used in combination with $0.4 \mathrm{~kg} \mathrm{~m}^{-2}$ of $\mathrm{CaO}$.

The extremely high fuel consumption and low operative times are the major disadvantages of mobile broad soil steaming applicators (Melander and Kristensen, 2011). In order to save energy and decrease the operative times, steam can be applied only in bands corresponding to the intra-row area, which is where weeds cause the most problems (Søresens et al., 2005; Raffaelli et al., 2016). Machines such as interrow cultivators can be used in the inter-band-steamed area (Elsgaard et al., 2010). Melander et al. (2004) developed a prototype band steamer able to apply steam in soil bandwidths of $80 \mathrm{~mm}$ at a depth of $50 \mathrm{~mm}$. Elsgaard et al. (2010) applied band steaming in a field study using a prototype with steaming tines that injected the steam produced by a $200 \mathrm{~kW}\left(720 \mathrm{MJ} \mathrm{h}^{-1}\right)$ steam generator at a depth of $50 \mathrm{~mm}$. Hansson and Svensson (2007) used a band-steaming prototype with a
$700 \mathrm{~kW}\left(2520 \mathrm{MJ} \mathrm{h}^{-1}\right)$ diesel-driven steam generator in order to apply steam in $105 \mathrm{~mm}$ wide soil bands at a depth of $50 \mathrm{~mm}$, and obtained a $90 \%$ weed control within the steamed bands. Raffaelli et al. (2016) designed and tested in real field conditions a prototype of a bandsteaming machine and found that by increasing the steam dose, the time for hand weeding, weed density and dry biomass at harvest were reduced, and consequently the carrot yield increased (Appendix Figure 1).

\section{Low-tech machines for intra-row weed control in post-emergence}

Mechanical methods for intra-row weed control are based on traditional spring-tine harrows and cultivators, but new devices have emerged, such as finger-weeders, torsion-weeders and intelligent weeders (van der Schans et al., 2006; van der Weide et al., 2008; Rasmussen et al., 2012). The choice of the right device is generally based on crop features, farm size, and cost.

Spring-tine harrows with flexible tines (or spring-tines) are generally used to carry out the false seedbed technique and in postemergence weed control in narrow row crops such as winter cereals. The spring-tines of the harrow control weeds by uprooting, covering small weed plants with soil, and damaging weed leaves. Weed harrowing can control small broad-leaved weeds effectively, and to a lesser extent deep-rooted weeds and grasses (Kurstjens and Kropff, 2001; Kurstjens et al., 2004). Spring-tine harrows are equipped with interchangeable round flexible spring-tines, usually made out of $6 \mathrm{~mm}$ diameter steel rods.

The aggressiveness of the harrowing can be adjusted by modifying the angle of the tines with respect to the normal soil surface. An angle of $-45^{\circ}$ respect to the normal soil surface represent the least aggressive setting, whereas an angle of $+15^{\circ}$ respect to the normal soil surface result in the most aggressive setting (Figure 2)

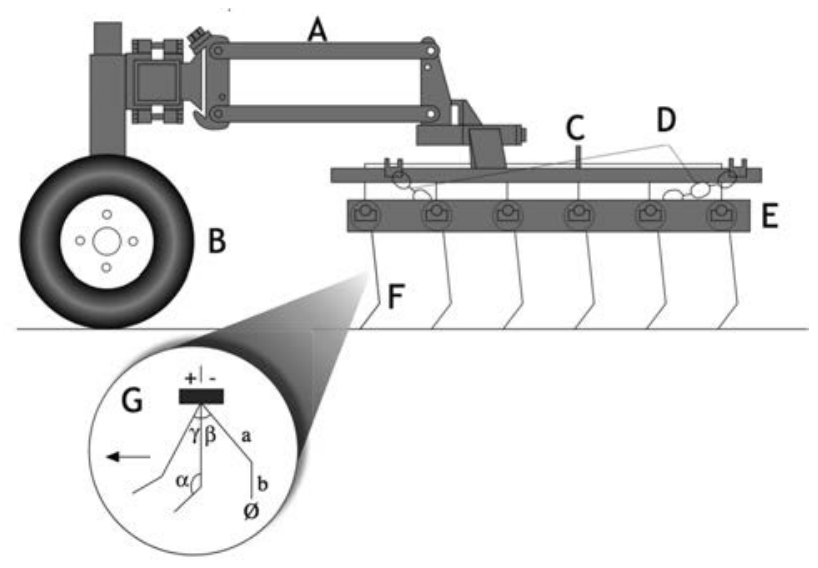

Figure 2. The spring-tine harrow: A) articulated parallelogram; B) gauge wheel; C) adjustment lever; D) chains; E) modular frame; F) spring-tine; $G$ ) shape and possible adjustment of the tines $\left(\alpha=135^{\circ} ; a=25 \mathrm{~cm} ; b=11 \mathrm{~cm}\right)$. Tine angle, with the perpendicular to the soil surface $(\beta)$, can be adjusted between $-45^{\circ}$ and $+15^{\circ}$. [Authors acknowledge Cambridge University Press as the source of the figure, which is taken from Peruzzi et al. (2007). This material cannot be reproduced, shared, altered, or exploited commercially in any way without the permission of Cambridge University Press, as it is copyrighted material and therefore not subject to the allowances permitted by a CC licence.] 
(Bàrberi et al., 2000; Cloutier et al., 2007; Peruzzi et al., 2007). The best results are usually obtained with tines angled slightly forwards, towards travel direction. The forward angle of the tines can be increased or decreased as required for the soil, weeds and crop. However, to maximise weeding the soil must not be too wet (van der Schans et al., 2006).

The functioning of these machines is independent of the distance between the crop rows. The working speed can vary from 3 to $12 \mathrm{~km} \mathrm{~h}^{-1}$ (van der Schans et al., 2006). Post-emergence harrowing occurs after the crop has emerged. It can be problematic, because both weeds and crop can be damaged by the tines of the harrow (Rasmussen et al., 2008). In this case the harrowing should be conducted when crop plants are significantly more resistant to soil disturbance than weeds (Melander et al., 2005). During harrowing, crop plants are sometimes covered with soil, but often to a lesser extent than the weeds and the crop usually recovers more quickly (Bond and Grundy, 2001). Smaller weeds are easily controlled by spring-tine harrows (Lundkvist, 2009). Selective harrowing is a special case of post-harrowing in which only the spaces between the crop rows are harrowed. Selective harrowing is usually performed with harrows with tines longer than those of the harrows used in ordinary post-harrowing, and it is carried out when the crop rows are easily identifiable (Lundkvist, 2009).

Cultivators with rigid blades that cut off the weeds one to two $\mathrm{cm}$ below the soil surface are the most commonly used machines for inter- and intra-row weed control. Mounting the tools on a parallelogram ensures that they follow the soil contours closely. The tension of the spring of the parallelogram can be adjusted to the soil structure. The spring pressure required to maintain depth in sandy soils is less than the pressure required to maintain depth in heavy clay soils. The spring settings depend on the type of parallelogram. The depth of the sharp tools can be adjusted in relation to the gauge wheels. The most uniform cultivating depth can be achieved with a minimum distance between the tools and the gauge wheels. The minimum row space required is $15 \mathrm{~cm}$. However, tools that are compatible with the row space need to be used. The working speed is generally low, but when the machine is equipped with a manual steering system, the speed can be higher (van der Schans et al., 2006). Cultivators are commonly equipped with goosefoot tools and may have protection shields. Such cultivators usually leave a minimum of a $10 \mathrm{~cm}$ uncultivated strip across crop rows (Ascard and Fogelberg, 2008). When used in combination with ridging plates, loose soil can be moved into the crop row to cover small weeds (van der Schans et al., 2006). The uncultivated strip in which the crop grows must be as narrow as possible, so that the level of weed control increases with every additional centimetre of cultivation. Manual steering systems have been developed to accurately follow the crop row. Manual guidance provides a high level of accuracy when operating close to individual crop plants.

Cultivators can be equipped with finger weeders or elastic tines for both inter and intra-row weed control (Cloutier et al., 2007; van der Weide et al., 2008). Elastic tines can act as both torsion weeders and vibrating tines, which differ depending on how the tips of the tines have been set. The vibrating tines work with the tips of the tines set in a vertical position, whereas the torsion weeders work with the tips of the tines set in a horizontal position (Figure 3) (Cloutier et al., 2007; Peruzzi et al., 2007). The shape and design of the tines, as well as the degree of compression and the distance of the tips from the crop plants, play an important role in the overall intensity of the treatment (Raffaelli et al., 2004; Cloutier et al., 2007; Ascard and Fogelberg, 2008; Fontanelli et al., 2015a). Wet conditions after cultivation decrease the level of weed control (Bond and Grundy, 2001) (Figure 4).

The rolling harrow is used for both the false seedbed technique and cultivation. This relatively unknown machine was designed, built and patented by the University of Pisa. The rolling harrow has spiked discs at the front, and cage rolls mounted at the rear on horizontal axles. The spiked discs and cage rolls are connected to each other by an overdrive with a ratio equal to 2 . The rolls thus work with a peripheral speed that is twice the speed of the discs. Discs and rolls can be placed in different ways on the horizontal axles. Discs and rolls are placed close together when the rolling harrow is used to prepare the seedbed and to achieve a non-selective mechanical weed control in the stale seedbed technique. On the

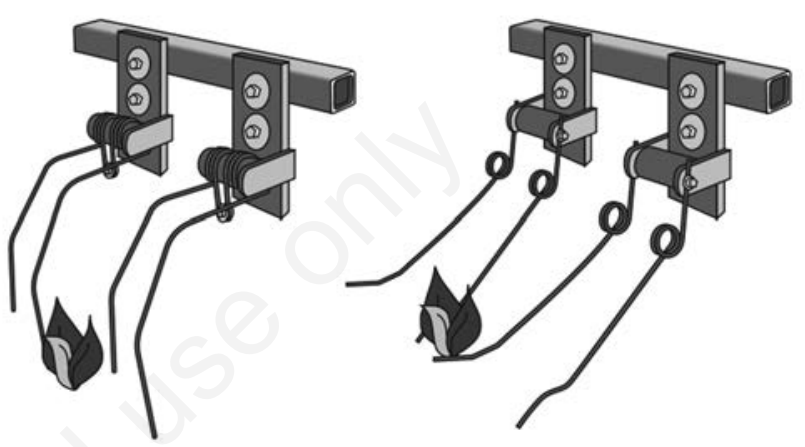

Figure 3. The vibrating tines (on the left) and torsion weeders (on the right). [Authors acknowledge Cambridge University Press as the source of the figure, which is taken from Peruzzi et al. (2007). This material cannot be reproduced, shared, altered, or exploited commercially in any way without the permission of Cambridge University Press, as it is copyrighted material and therefore not subject to the allowances permitted by a CC licence.]

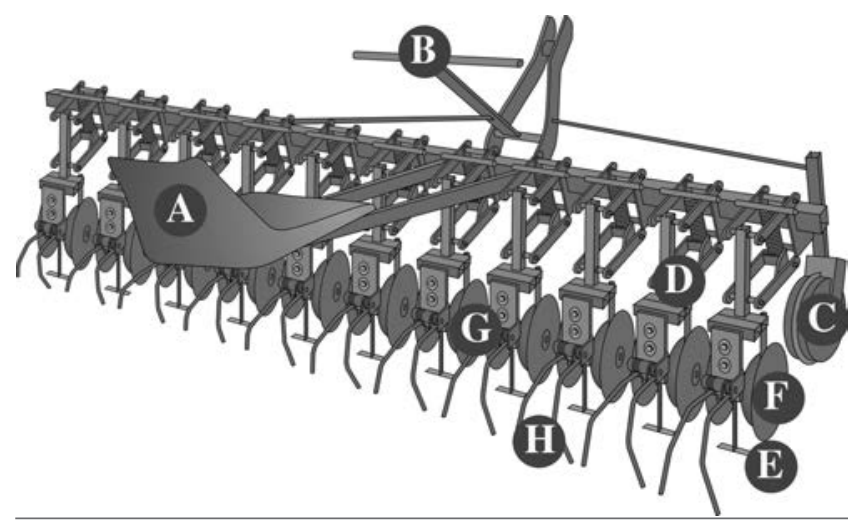

Figure 4. The cultivator built by Peruzzi et al. (2007) for both inter and intra-row weed control: A) seat; B) handlebars for steer; C) directional wheels; D) articulated parallelogram; E) blade tools for inter-row weed control; F) protective disk; G) gauge wheel; H) vibrating tines. [Authors acknowledge Cambridge University Press as the source of the figure, which is taken from Peruzzi et al. (2007). This material cannot be reproduced, shared, altered, or exploited commercially in any way without the permission of Cambridge University Press, as it is copyrighted material and therefore not subject to the allowances permitted by a CC licence.] 
other hand, discs and rolls are spaced out for a post-emergence inter-row weed control. The spiked discs till the first 3-4 cm of the soil. The rolls then till and crumble the first $2 \mathrm{~cm}$ of the soil, at a higher peripheral speed. The rolling harrow is particularly suitable for breaking down the clods where small weed seedlings could survive, and can also be used in plastic and wet soils. The rolling harrow can be equipped with elastic tines and a hand steering system for inter and intra-row weed removal very close to the crop plants (Figure 5) (Cloutier et al., 2007).

A finger weeder is made up of a pair of disks that have peripheral fingers and can be inclined in relation to the soil surface (Appendix Figure 2). The disks rotate when they make contact with the soil. The fingers can be made of rubber-coated iron (hardfinger) or of plastic (soft-finger) (Cloutier et al., 2007). The finger weeders uproot weeds and lift them out of the crop row. Small finger weeders require a row space ranging from a minimum of $25 \mathrm{~cm}$ to a maximum of $35 \mathrm{~cm}$, whereas large finger weeders require a minimum row space of $35 \mathrm{~cm}$. Finger weeders perform well on light to medium-heavy clay soils, but are not suitable for soils that are too hard. The working speed can range from 4 to $12 \mathrm{~km} \mathrm{~h}^{-1}$. The aggressiveness of the cultivation increases by decreasing the distance between the fingers, which can be achieved by moving closer the disks bearing the fingers. With young crops the fingers should be set at a distance of $2 \mathrm{~cm}$ from each other. The distance between the fingers can be reduced once the plants are firmly rooted. The fingers may overlap with sturdy crops (maximum of $5 \mathrm{~cm}$ ). The soil must be readily workable, and preferably dry. Soil that is too wet sticks between the fingers and the drive. Harder fingers are preferable for heavy clay soils, and softer fingers for light soils. A steering system can help ensure that the crop row is aligned between the finger weeders (van der Schans et al., 2006; Cloutier et al., 2007).

Torsion weeders consist of a pair of spring tines per row, pointing into the crop from either side of the row but under the crop leaves. Tines with different diameter (ranging from 4 to $8 \mathrm{~mm}$ ) can be interchanged, according to the crop growth stage and sensitivity to mechanical damage. Torsion weeders uproot the weeds shallowly. The crop must pass precisely between the tines of the torsion weeders. The aggressiveness of the cultivation increases by decreasing the distance between the tips of the two spring tines, and increasing their compression. The spring tines can overlap each other $(1-5 \mathrm{~cm})$ when the crop plants are well rooted. Spring tines are most effective when their tips are angled slightly downwards. The tines are generally set almost together $(0-0.5 \mathrm{~cm}$ spacing). The working speed can range from 4 to $12 \mathrm{~km} \mathrm{~h}^{-1}$. The minimum row space required is $25 \mathrm{~cm}$. The soil must be readily workable, and preferably dry. The effect is poor in very heavy clay soil, since the spring tines are not able to penetrate it. In light soil can be used $7 \mathrm{~mm}$ thick tines, whereas in heavy soil are preferable 11 mm thick tines (van der Schans et al., 2006; Cloutier et al., 2007; Ascard and Fogelberg, 2008; Fontanelli et al., 2015a). Working at higher speeds with the torsion weeders results in a better weed control, with no yield reduction compared with a lower speed. Weeds have to be small to be controlled effectively by torsion weeders. Weeding should be conducted frequently, maybe each week in the early crop stages (Ascard and Fogelberg, 2008). The use of a steering system ensures that the crop row is kept between the tines of the torsion weeders (van der Schans et al., 2006).

Both finger and torsion weeders treat both weeds and crops when passing through the intra-row area. Weeding effectiveness is inversely related to the weed growth stage at the time of treatment, and crop plants need to be more resistant to soil disturbance than weeds (Melander et al., 2005). In some cases the damage caused by mechanical in-row weed control seems to be considerably less than the yield losses due to weed competition (Ascard and Fogelberg, 2008).

It is crucial to ascertain the ideal number of treatments and the right settings for the machine (Ascard and Fogelberg, 2008). Generally torsion and finger weeders are more selective than spring-tine harrows, especially in broad-leaved crops (Bleeker et al., 2002; Ascard and Fogelberg, 2008). Bleeker et al. (2002) observed a tendency for better weed control but also a greater crop plant reduction with the torsion weeder compared to the finger weeder.

\section{Low-tech intra-row weed control in narrow-row crops}

Weed harrowing is the cheapest and oldest solution for controlling weeds in narrow-row herbaceous crops without using chemicals (Bàrberi et al., 2000). The main mortality factor for small seedlings is the uprooting and removal of the plants (Kurstjens and Kropff, 2001; Cirujeda et al., 2003). The amount of uprooted weeds is not affected by the driving speed, as passing from 2 to 8 $\mathrm{km} \mathrm{h}^{-1}$ does not result in a higher weed control efficacy (Cirujeda et al., 2003). Cirujeda et al. (2003) found that wheat and barley biomass was not affected by increasing speed, so that faster treatments were recommended.

Bàrberi et al. (2000) found that weed harrowing, conducted alone both under conventional tillage and no-tillage, did not

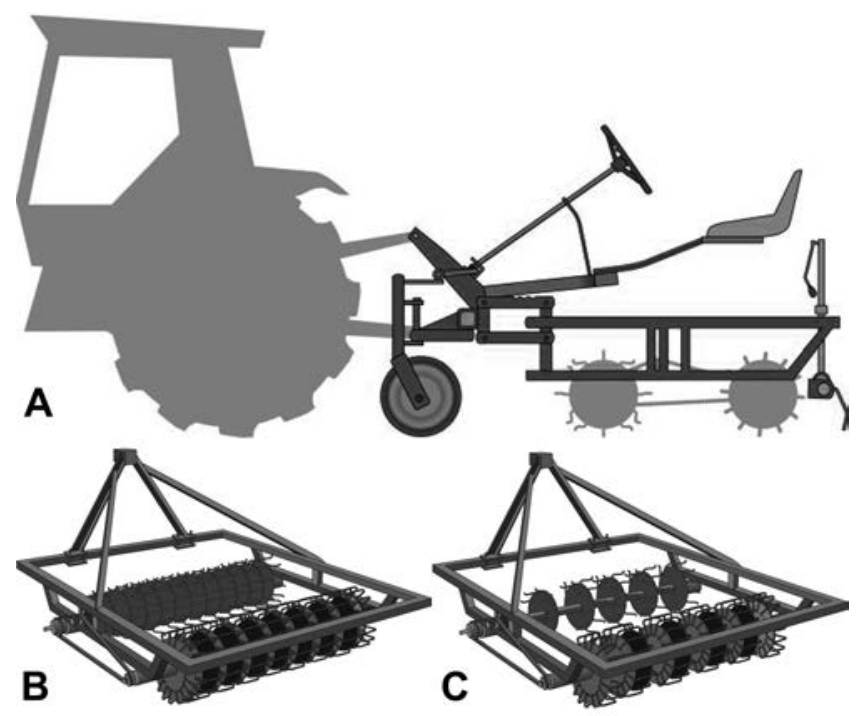

Figure 5. The rolling harrow: A) front view of the rolling harrow equipped with a manual steering system and vibrating tines to conduct inter and intra-row cultivation; $B$ ) close arrangement of the tools for non-selective treatments; C) spaced arrangement of the tools for inter-row cultivation. [Authors acknowledge Cambridge University Press as the source of the figure, which is taken from Raffaelli et al. (2010). This material cannot be reproduced, shared, altered, or exploited commercially in any way without the permission of Cambridge University Press, as it is copyrighted material and therefore not subject to the allowances permitted by a CC licence.] 
always guarantee sufficient weed control and grain yield in winter wheat. Raffaelli et al. (2002) found that controlling weeds in sunflower and soybean by using the spring-tine harrow did not reduce yields compared with the application of herbicides. Moreover, yields and weed control were not affected by the spring-tine adjustment. Lundkvist (2009) found that the best weed control in spring cereals and peas with harrowing was obtained by combining preand post-emergence harrowing, but these treatments also caused yield losses of $12-14 \%$ in spring wheat and oats, while no yield losses were observed in peas. Probably these differences were due to the different plant habits or anchorage levels of the crop. Jensen et al. (2004) found that weed harrowing in lupin was effective because the crop soil cover recovered well.

Selective harrowing, i.e. inter-row harrowing in late growth stages of the crop, is a relatively new concept in weed harrowing in narrow row-crops. Selective harrowing is a special case of postharrowing in which only the spaces between the crop rows are treated. Selective harrowing is usually performed with longer tines than those of the machines used to conduct ordinary post-harrowing and at a later crop stage, when the crop rows are easily identifiable (Lundkvist, 2009). Selective harrowing is selective in the sense that a high degree of weed control can be obtained without associated crop damage that eventually result in crop yield losses. Rasmussen and Svenningsen (1995) found that the weed control level of selective harrowing was comparable to herbicide spraying when it was conducted in spring barley and winter wheat. High intensities of harrowing result in some crop damages in spring barley, but not in winter wheat (Rasmussen and Svenningsen, 1995).

Rasmussen et al. (2010) found no yield reduction when selective harrowing was conducted on spring barley, even if the recovery of crop and weeds was influenced by the timing of harrowing. Thus, timing of selective post-emergence weed harrowing was not found to be crucial, given the condition that the aggressiveness of the machine was calibrated to the growth stage (Rasmussen et al., 2010). Hansen et al. (2007) found that spring barley varieties which were tall at post-emergence harrowing and had increased density after pre-emergence harrowing, benefitted the most from this treatment.

A relatively new method for weed control in narrow-row crops is inter-row cultivation (Pannacci and Tei, 2014). With a springtine harrow, the entire surface of the field is treated, and the crop plants are exposed to the same treatment as the weed plants. With an inter-row cultivator only the weed plants between the crop rows are treated and the crop plants are, ideally, left undisturbed. Interrow cultivators can be more effective than harrows, but they require a wider than normal row spacing (Rasmussen, 2004). Rasmussen (2004) used an inter-row cultivator in winter wheat planted on $24 \mathrm{~cm}$-spaced rows. They found that the yields decreased only in experiments with low weed pressure, whereas at intermediate weed levels there were no differences and at high weed pressure the cultivator led to a yield increase compared with the untreated control planted at $12 \mathrm{~cm}$. Cultivation combined with selective harrowing gave very high degrees of weed control without the associated crop damage (Rasmussen and Svenningsen, 1995).

Mechanical weed control in narrow-row horticultural crops can be performed by adjusting the plant stand in single rows and by adopting a controlled traffic farming system or raised beds.

Peruzzi et al. (2007) optimised the plant stand of carrot in order to physically control weeds at a farm level, where only hand weeding was conducted in carrots sown in bands. Carrots were sown in single rows by maintaining the same seed rate as carrot sown in bands. The inter-row space was $18 \mathrm{~cm}$ and a custom built cultivator equipped with a manual steering system was built to conduct intra-row weed control without damaging the crop. The whole weed control strategy included the stale seedbed technique (harrowing plus flame weeding) conducted prior to emergence. The cultivator weeding tools were $T$-shaped blades, protective discs for the inter-row weed control, and elastic tines (torsion weeders or vibrating tines) for intra-row weed control. The comparison between an inter-row cultivator tilling an inter-band space of $30-\mathrm{cm}$ in carrot sown in $10-\mathrm{cm}$ wide bands and the use of the intra-row cultivator working in single row sown carrot $(18-\mathrm{cm}$ inter-row space) revealed that yields were higher by $23 \%$ to $30 \%$ when the intra-row cultivator was used, and hand weeding times were reduced from $28 \%$ to $41 \%$ (Peruzzi et al., 2007).

Raffaelli et al. (2010) used a similar intra-row cultivator equipped with the manual steering system, goose-foot tools and elastic tines for inter- and intra-row weed control, respectively, in a $20-\mathrm{cm}$ wide row leaf-beat crop. Before post-emergence weed control, the stale seedbed technique was conducted using the rolling harrow and a flamer prior to crop emergence. Leaf-beat yields were similar compared to those measured in a weed management system based on the use of herbicides.

Fontanelli et al. (2015b) combined the use of the same intrarow cultivator used by Raffaelli et al. (2010) and the rolling harrow for post-emergence weed control in spinach planted in $20 \mathrm{~cm}$ wide spaces between rows on raised beds. A complete weed management strategy, consisting in a stale seedbed technique (rolling harrow plus flaming in pre-emergence of the crop) in addition to the post-emergence interventions, avoided the use of hand weeding and led to higher yields (from $20 \%$ to $33 \%$ ) compared to weed control conducted with herbicides.

\section{Low-tech intra-row weed control in wide-row crops}

Wide-row crops are typically grown at 0.3-0.7 m row spacing, to allow the weeding tools to pass between the rows. Wide-row crops potentially create two different situations for physical weed control: i) weeds that grow in the inter-row space, which can be easily removed by inter-row cultivators; ii) weeds in the intra-row line, which are still a major challenge in choosing the most appropriate weeder for the specific crop, and require time-consuming hand-weeding (van der Weide et al., 2008; Melander et al., 2015).

Weed control in the intra-row is particularly troublesome in low competitive crops such as carrot, onion and leek (Melander and Rasmussen, 2001). Manual intra-row weeding can be expensive and time consuming, particularly in slow-growing and low competitive crops (van der Weide et al., 2008). An inter-row cultivator can drastically reduce the direct costs of hand weeding in small-sized low-competitive crops, such as carrot, spinach, fennel, and dry bean (Peruzzi et al., 2007; Fontanelli et al., 2015a; Martelloni et al., 2016b).

Cultivators with manual steering systems are essential for postemergence weed control very close to the crop row, and they also bury weeds within the rows (Martelloni et al., 2016b). Fontanelli et al. (2015a) compared post-emergence weed control in fennel with a cultivator equipped with a manual steering system and one without the steering system, and found a higher yield and lower dry biomass of the weeds at harvest when the cultivator equipped with manual steering system was used.

Raffaelli et al. (2004) tested a spring-tine harrow at different tine adjustments in string bean seeded at an inter-row space of 75 
$\mathrm{cm}$ and found that yields were not affected by the tine adjustment or by the number of applications (one or two). They also compared a cultivator provided with a manual steering system and equipped with different weeding tools: $L$-shaped and goose-foot tools for inter-row weed control alone, and $L$-shaped and goose-foot tools for inter-row weed control plus torsion weeder with tines set almost together or overlapping each other for intra-row weed control. Results showed no differences in string-bean yields when the different settings of the cultivator tools were compared. The same machines used in maize $(50 \mathrm{~cm}$ row width) gave a higher yield when weed control was conducted with the cultivator compared to the spring-tine harrow, but also in this case no differences in terms of maize yield were found between tine adjustments of the springtine harrow and the settings of the cultivator (Raffaelli et al., 2005). Vangessel et al. (1995) tested an intra-row cultivator equipped with different tools such as torsion and spring hoe weeders in maize, and found a 54\% higher weed control compared with a standard cultivator, while the cost of operating the two cultivators was similar.

Melander and Rasmussen (2001) compared a cultivator with a brush weeder for intra-row weed control in onion and leek. The cultivator consisted of individual units equipped with three goosefoot tools and two toothed protective discs. Each unit cultivated the inter-row area between two crop rows. The cultivator worked close to the row leaving only a $5 \mathrm{~cm}$ untilled strip in the crop rows. The goosefoot tools worked at a soil depth of 1-2 $\mathrm{cm}$ and a driving speed of $6 \mathrm{~km} \mathrm{~h}^{-1}$. The cultivator was steered using a conic wheel, thus no extra person was involved besides the tractor driver. The brush weeding was conducted twice with a vertical axis rotary brush. The first pass uprooted the weeds within the working area of the brushes and then threw them sideways. During the second pass, the brushes not only controlled weeds beneath the brushes but also smaller weeds in the crop row were controlled by soil coverage, since some soil was thrown into the crop row thus creating a small ridge. The working depth of the brushes was about $2 \mathrm{~cm}$ at both passes, and the driving speed was $1.5 \mathrm{~km} \mathrm{~h}^{-1}$. The machine was rear-mounted and manually steered. Melander and Rasmussen (2001) found that the brush weeder was more effective in controlling weeds than the cultivator, but only slightly better, and the cultivator was cheaper both in terms of investment and use (Melander, 1998).

Ascard and Fogelberg (2008) found that in onions, a treatment applied 12 days after transplant with a spring-tine harrow, equipped with round $7 \mathrm{~mm}$ flexible tines and driven at a speed ranging from 3.5 to $6 \mathrm{~km} \mathrm{~h}^{-1}$, followed by three inter-row cultivation plus torsion weeding ( $8 \mathrm{~mm}$ flexible steel tines at $0-0.5 \mathrm{~cm}$ spacing) in the intra-row applied at varied speeds ranging from 1.5 to $5.4 \mathrm{~km} \mathrm{~h}^{-1}$ reduced in-row weeds by $83-86 \%$ compared with cultivation or weed harrowing only. This was irrespective of the speed used, and the yield was not lower than with harrowing alone and there was a $3 \%$ higher yield compared with inter-row cultivation alone.

Raffaelli et al. (2011) used a custom built $V$-shaped tool to conduct weed control in an advanced growth stage of tomato transplanted in pair rows 40 -cm wide. The $V$-shaped tool was mounted on a cultivator equipped with a manual steering system. This enabled the tool to open up the vegetation by passing exactly between crop rows and inter- and intra-row; weed control was carried out by using goosefoot tools and elastic tines without damaging crop leaves. This arrangement of the cultivator, controlling weeds until the pre-flowering stage of tomato, led to higher yields than when the weed control was conducted with herbicides.

Fontanelli et al. (2013) compared post-emergence weed con- trol in tomato conducted with a cultivator equipped with a manual steering system, $L$-shaped tools and torsion weeders alone, with straw in the intra-row and the use of an inter-row cultivator outside the mulching straw, and weed control conducted with a plastic film. They found that although the weed dry biomass at harvest was similar, the yield where mulching was used was higher compared with the mechanical weed control alone, probably because mulching meant that weeds were better controlled in the critical period of weed control.

\section{Thermal solutions for intra-row weed control}

Mechanical devices for weed control may disturb the upper soil layer and this can stimulate new weed seed germination. Moreover, many weed seedlings rooted in the clods still continue to grow. These undesirable effects can be avoided by using thermal methods. Thermal methods can be used when the soil is too wet for mechanical weeding without soil disturbance, which then stimulates further weed emergence. Plant tissues are susceptible to high temperatures, when most of the physiological functions are disrupted because of membrane rupture, protein denaturation, and enzyme inactivation. This has led to the development of weed management strategies involving high temperatures. Flaming and microwave technologies can be used to control weeds in the postemergence of the crop. Zhang et al. (2012) researched about the use of hot vegetable oil to control weeds and found this technique promising.

\section{Flamers for intra-row weed control in heat toler- ant crops}

Flaming kills weeds through the use of direct heat in the form of fire and avoids tilling the soil. Flame weeding devitalises weed seedlings through the effect of high temperatures that denaturise plant proteins (Raffaelli et al., 2013). Flaming is not influenced by soil type, resistance or moisture because the weeding mechanism is not based on tilling the soil and uprooting weeds, but on the effect of high temperatures that denaturise plant proteins and thus desiccate the weeds, normally within two to three days (Mojžiš, 2002).

Flaming can be applied in the inter-row of all crops with a space between the rows from $30 \mathrm{~cm}$ upward. The working speed commonly ranges from 3 to $6 \mathrm{~km} \mathrm{~h}^{-1}$ (van der Schans et al., 2006). Importantly, flame weeding can control weeds in the intra-row of all heat-tolerant and low-competitive crops such as onions, chicory, sown leek, garlic, and day bean (van der Schans et al., 2006; Sivesind et al., 2012; Fontanelli et al., 2015a; Martelloni et al., 2016b), as well as in wide-row heat-tolerant herbaceous crops such as maize, soybean, sunflower, and sorghum (Peruzzi and Raffaelli, 2000; Ulloa et al., 2011a, 2011b; Martelloni et al., 2016b).

The effectiveness of flaming is affected by the type and adjustment of the burners, the doses, and the weed and crop growth stage (Raffaelli et al., 2015). Water droplets on the leaves can reduce the effect of heat (van der Schans et al., 2006).

The most common burners used in agriculture are open flame burners: atmospheric and self-vaporizer. Open flame burners can be fed by propane or LPG in gaseous or liquid phase. They can have a cylindrical, truncated-conic, prismatic, or truncated-pyramidal shape. The prismatic or truncated-pyramidal shape produces a controllable flame suitable for homogeneous applications on 
defined targets (Raffaelli et al., 2015).

Raffaelli et al. (2015) developed a new kind of open flame atmospheric burner fed by LPG. They built a pre-mix burner, where the mix between gas and air occurs before the combustion chamber in an external mixer by the Venturi effect (primary air intake). There is a secondary air intake directly during the combustion, which improves the efficiency of the combustion itself. This kind of burner generates a short flame at a high temperature. These burners have a prismatic shape and are based on Reinert burners, which are LPG-fed open flame atmospheric burners.

A flamer with a custom-built heat exchange system was developed at the University of Pisa. The exhaust gases are transferred from the engine to the hoppers containing water and the LPG tanks (Figure 6). Heating the water by exhaust gases prevents the LPG from cooling down to below the temperature of vaporisation and ensures that the gas keeps flowing. This flamer can be equipped with a maximum of four LPG tanks, four or eight burners $50 \mathrm{~cm}$ or $25 \mathrm{~cm}$ wide, respectively, for a total working width of $2 \mathrm{~m}$. The burners can be easily regulated by varying the height and the inclination with respect to the soil surface.

For effective weed control, burners are commonly set at a height of 7-10 cm from the soil and at an inclination of $30^{\circ}-45^{\circ}$ with respect to the perpendicular to the ground. The height of the burners from the soil is regulated by articulated parallelograms on which the burners are set and by the gauge wheels. The LPG tanks are connected to a pressure regulator and a manometer, which are linked to a control system. The control system of each burner consists of two electro valves, one for the ignition of the pilot flame and the other for working at the adjusted pressure, plus one safety electro valve. The safety electro valve is connected to a thermocouple located inside the burner, and it closes the LPG flow if the flame goes out (Raffaelli et al., 2013).

The key to flame weeding is to position the burners so that the growing point of the crop is protected (Datta and Knezevic, 2013). The position of burners is generally regulated depending on whether broadcast flaming or cross flaming is required. Ulloa et al. (2011b) investigated the response of sorghum to broadcast flaming as influenced by propane dose and crop growth stage. The results highlighted that the maximum yield reductions caused by the use of the highest propane dose of $85 \mathrm{~kg} \mathrm{ha}^{-1}$ were $11 \%, 6 \%$, and $9 \%$ for 3-leaf, 5-leaf, and 7-leaf growth stages, respectively.

Fontanelli et al. (2015a) applied broadcast intra-row flame weeding in garlic in addition to using the stale seedbed technique and post-emergence weed control with a cultivator. They found higher yields and lower weed dry biomass at harvest compared to the weed management conducted with hand weeding alone. Ulloa et al. (2011a) tested the response of maize to broadcast flaming. The 5-leaf growth stage (fifth leaf with visible collar) was the most tolerant to broadcast flaming, whereas the 2-leaf growth stage was the most susceptible (second leaf with visible collar), resulting in the highest visual crop injury ratings, dry matter reduction and the largest loss of yield.

Cross flaming consists in applying a direct flame on a soil band corresponding to the line of the crop (Appendix Figure 3). This then kills weeds in the intra-row space. A pair of open-flame burners produce a direct double flame that acts on the intra-row space, with crop plants placed in the middle. The burners are angled at $45^{\circ}$ from the perpendicular to the ground and parallel to the crop row, and positioned at about $10 \mathrm{~cm}$ from each side of the crop row and $12 \mathrm{~cm}$ above the soil surface.

Peruzzi and Raffaelli (2000) tested maize, sunflower and soybean heat-tolerance to cross flaming and found no damage compared with the untreated control at the end of the growth stage.
Raffaelli and Peruzzi (2002) applied cross flaming in sunflower and found no yield reduction compared with the yield measured when a herbicide was used. Knezevic et al. (2013) applied a propane dose of $50 \mathrm{~kg} \mathrm{ha}^{-1}$ parallel to the soybean rows and found that soybean can tolerate a maximum of two flaming treatments at unfolded cotyledonary and fifth trifoliate growth stages per season without any reduction in yield. Martelloni et al. (2016b) used cross flaming at different growth stages of dry bean. They found that when flaming was applied at BBCH 14 (second trifoliolate, counted when leaf edges no longer touch) with an LPG dose of $39 \mathrm{~kg} \mathrm{ha}^{-1}$, yields were similar compared to mechanical weed control conducted with a cultivator equipped with a steering system and the weed free control.

The propane or LPG dose depends on the weed and crop growth stage. For an effective weed control, repeated applications may be needed. Datta et al. (2013) tested single and repeated flame weeding on maize in weed-free conditions with a propane dose of $50 \mathrm{~kg} \mathrm{ha}^{-1}$. Burners (Flame Engineering, 2007) were positioned parallel to the crop row and covered with specially designed hoods. The hoods were positioned over the intra-row space and were closed across the rows during flaming. Results showed that yields of maize flamed once (at the second leaf with visible collar) and twice (at the second and fourth leaf with visible collar) were similar to the yield observed in the non-flamed control. Martelloni et al. (2016a) found that repeated cross-flaming in maize (at the second leaf with visible collar and 16-day later) with an LPG dose ranging from 36 to $42 \mathrm{~kg} \mathrm{ha}^{-1}$ controls weeds and prevents yield losses due to both weed competitiveness and maize injury.

Further studies on the applicability of flaming for intra-row weed control in post-emergence are required because each crop has its own threshold of heat tolerance at different growth stages. Studies should also assess whether the doses tolerated by crops are sufficient to control weeds. The response of weeds and crops to flaming needs thus to be evaluated while growing together in a real field situation (Martelloni et al., 2016a, 2016b).

Flame weeding can also be used to control weeds in systems that provide strip tillage. Strip tillage focuses on targeted tillage for crop sowing, while the remaining portion is untilled. In this case, flaming could be a valid alternative to herbicides for controlling weeds in the untilled zones (Frasconi et al., 2016).

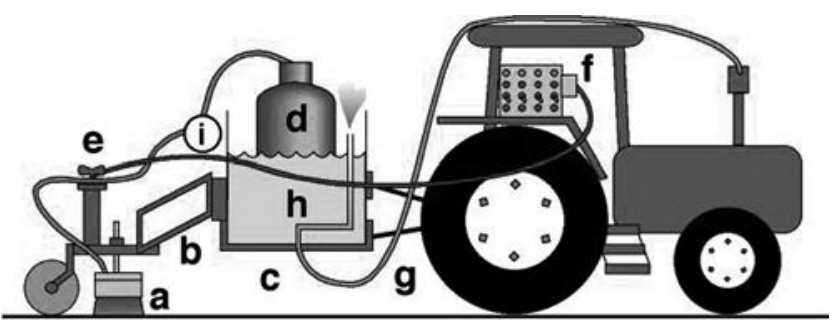

Figure 6. The flame weeder. a: burner; b: articulated parallelogram; c: hopper; d: LPG tank; e: shelf on which the inflow LPG control is located; $f$ : control panel; g: flexible pipe that pipes the exhausted gas of the tractor engine to the heat exchanger in the hopper; h: water (heat-exchanger); i: pressure regulator with manometer. [Authors acknowledge Cambridge University Press as the source of the figure, which is taken from Peruzzi et al. (2007). This material cannot be reproduced, shared, altered, or exploited commercially in any way without the permission of Cambridge University Press, as it is copyrighted material and therefore not subject to the allowances permitted by a CC licence.] 


\section{Laser radiation technology}

Thermal weed control with flaming is limited to selective applications. Laser technology could be an alternative tool. Lasers have been considered as a valid cutting device for physical weed control. Extensive research on the effects of laser treatment as a weed control method has been carried out in recent years. The results have shown that the laser can significantly inhibit the growth of weeds (Ge et al., 2013).

With lasers, only the meristems (growth centre) of the weeds need to be treated, as this has an effect on the entire plant. Laser irradiation leads to the absorption of energy in the plant tissue and usually to a conversion into heat, through which the meristem is destroyed. The critical point during the large-scale use of laser technology is to focus the laser light at the correct point of the weeds. Particularly important are: the laser wavelengths, radiation intensities, technically feasible targeting devices, as well as the weed species and their growth stages (Mathiassen et al., 2006; Marx et al., 2012b). Mathiassen et al. (2006) showed that the optimisation of targeting accuracy, laser spot size, and energy density may improve the laser application.

Laboratory experiments have highlighted that differences in the efficacy of the treatment depend on the plant species and growth stage. The more open growth of dicotyledons makes them more accessible for the laser beam rather than the more closed growth of monocotyledons. Larger plants were only affected by higher energy, small plants were successfully treated at lower doses (Wöltjen et al., 2008). Small weeds are more sensitive to laser treatments at high intensity. Marx et al. (2012a) found that monocotyledonous 2-leaf-plants were damaged at a high energy level, whereas 4-leaf plants were difficult to kill. Dicotyledonous 2-leaf-plants were already damaged with moderate intensities. Thus, damage to monocotyledonous required higher laser doses compared to doses able to damage to dicotyledonous. The influence of the spot position was important, as the unfocused treatment resulted in a decreased lethality (Marx et al., 2012a).

The adsorption of laser radiation in plant tissue is dependent on the wavelengths of the laser used. Only lasers with a high degree of absorption in the plant tissue should be used for weed control (Marx et al., 2012b). It was found that an energy of at least $54 \mathrm{~J}$ per monocotyledonous plant was necessary to lethally damage each treated plant. As the proportions of the distribution of monocots and dicots are field-specific, at least these $54 \mathrm{~J}$ should be available (Marx et al., 2012a).

Laser weeding prototypes have been developed for laboratory applications or for the greenhouse (Mathiassen et al., 2006; Marx et al., 2012b; Ge et al., 2013). Laser weeding robots can improve labour productively, solve the shortage of the labour force, improve the environment of agricultural production, improve work quality, reduce energy waste, improve resource utilisation, and help farmers to change their traditional working methods and conditions (Ge et al., 2013). Simulation results indicate that fast-moving farm machinery on larger weed densities require a higher laser power, but cannot be injected adequately into plant tissue. Slow moving field machines of autonomous field robots in stop-and-go operation could be more effective (Marx et al., 2012b).

\section{Robotic weed control}

The advances in technology have created wide opportunities for weed management, and precision agriculture may become a key element of modern weed control (Bajwa et al., 2015). Precision weed management is based on exploiting information technology for decision-making about site-specific weed control (Christensen et al., 2009). Spatial heterogeneity in weed infestation provides the basis for such systems (Freckleton and Stephens, 2009). With the progress in robotics research for agriculture, robots can now be used for weed control (Young et al., 2014). Worldwide, there are considerable financial resources being allocated for research and development in agricultural applications involving robotics and nanotechnology (Shaner and Beckie, 2013). GNSS and machine vision technologies enable the site-specific management of farming practices and resources in an attempt to optimise production efficiency while minimising environmental costs (Slaughter et al., 2008).

A general-purpose autonomous robotic weed control system has four core technologies: guidance, weed detection and identification, precision in-row weed control, and mapping (Slaughter et al., 2008). Slaughter et al. (2008) stated that robust weed detection and identification was the primary obstacle to the commercial development and industry acceptance of robotic weed control technology. The introduction of automatic weed control actuators could improve the speed and working width of the machines. Intelligent machines could replace the need for skilful and experienced operators (van der Weide et al., 2008; Slaughter et al., 2008). Consequently, the automation of mechanical and thermal weed control could contribute to sustainable food production at a lower cost (Bakker et al., 2010).

\section{Mechanical automated implement}

Although much research has focused on developing robotic machines for mechanical intra-row weed control (Åstrand and Baerveldt, 2005; Nørremark et al., 2008; Bakker et al., 2010; Nørremark et al., 2012; Pérez-Ruíz et al., 2012, 2014), robotic weeding on a commercial scale is still in its infancy. There are only four intra-row robotic weeders commercially available: the Robovator, produced by Frank Poulsen Engineering Aps. (Hvalsø, Denmark); the Robocrop, developed in England by Tillett and Hague Technology Ltd. (O'Dogherty et al., 2007; Tillett et al., 2008); the IC-Cultivator, manufactured by Machinefabriek Steketee BV in the Netherlands; and the Remoweed, produced by Costruzioni Meccaniche Ferrari in Italy (Costruzioni Meccaniche Ferrari, 2015).

Robovator cuts weeds at $1-2 \mathrm{~cm}$ soil depth by using a pair of tines each equipped with a flat knife-like blade. The blades cultivate the inter- and the intra-row area. When blades approach a crop plant, the blades move apart to avoid damaging the plant. When the plant has been passed, the blades close immediately to continue cultivating the intra-row area. The movement in and out of the crop row is performed by a hydraulic actuator connected to a camera mounted in front of it. There is a camera for each crop row that detects each crop plants based on the different in size between the crop plant and the weeds. The images are processed by a computer that calculates the points at which the actuator of the blades needs to be activated based on the driving speed and the area never cultivated near the crop plants (Melander et al., 2015). Multiple modules can be mounted on a toolbar to provide wider working widths (Siemens, 2014).

Robocrop is a tractor-mounted cultivator based on a commercially available steerage hoe, equipped with common inter-row cultivation blades, fitted with two hydraulically driven disc modules for each crop row. The discs rotate on a vertical axis. As the 
cultivator advances down the row, a rotating disc controlled by a vision system detects the crop plant location and rotates to align the disc's cut-away section with the saved crop plant. The discs are mounted on a depth control wheel and set to cultivate at a shallow depth (typically $20 \mathrm{~mm}$ ) within the crop rows. Due to variability in crop plant spacing, crop damage is avoided by cutting out a section from the disc's plan profile and rotating it in synchrony with a forward movement in order to ensure that the cut-out section always coincides with the crop plant. The minimum inter-row distance required is $25 \mathrm{~cm}$ (Tillet et al., 2008).

The IC-Cultivator uses cameras, one for each row, to determine the position of the crop plants in real-time for guidance. The plant position is calculated according to the colour, size and expected position. The device can be equipped with a variety of tools (e.g., blades and tines) to guarantee a high level of weed control between and in the crop rows of the crop. A pneumatic cylinder is actuated to open and close the tools around the crop plants. The device is modular, providing working widths ranging from 1.5 to 6 $\mathrm{m}$, and is able to remove weeds from 3-4 crop plants along the row in one second. During the operation additional information can be collected such as the density, the cover and a possible alteration in colour of the crop (Machinefabriek Steketee BV, 2016; Siemens, 2014).

Remoweed detects crop plants in real-time using infrared light sensors. The machine removes weeds both from the inter- and intra-row space by using cutting blades, which can cut weed plants under leaf without any risk for the crop. The working height of the blades can be adjusted by the operator while opening and closing speeds are automatically set according to the working speed and type of soil. The automatic hoe is equipped with a floating frame able to shift laterally with respect to the driving direction by using hydraulic pistons. It needs a minimum row-distance of $27 \mathrm{~cm}$ and can remove weeds from 12,000 crop plants $\mathrm{h}^{-1}$ per row. The distance from crop plants and weed blades is adjustable from 0 to 10 cm (Costruzioni Meccaniche Ferrari, 2015).

All these machines are primarily suited for crop stands with sufficient spacing between crop plants in the row (about 15-30 $\mathrm{cm}$ ), as well as between rows (not less than $20 \mathrm{~cm}$ ), and where there is a large size differential between emerging weeds and crop plants. The large space needed between crop plants in the row represents a substantial limitation for the practical adoption of these machines in crops in which the number of plants seeded or transplanted is potentially the same as the number that will be harvested. The yield per hectare of crops with stand features adapted to the needs of the machines is lower than a normal crop stand. For example, in onion, Melander and Rasmussen (2001) recommend stands of 30-35 plants per metre, whereas when testing the Robovator, Melander et al. (2015) used stands of only three plants per metre. Melander et al. (2015) compared the Robovator in terms of weed control efficacy and crop tolerance, with a non-intelligent torsion weeder, spring-tine harrow and finger weeder in transplanted onion (Allium cepa L.), and with a non-intelligent spring-tine harrow and finger weeder in transplanted cabbage (Brassica oleracea var. capitata $\mathrm{L}$.) Weeds that had only developed cotyledons and up to 1-2 true leaves at the time of treatment, when non-intelligent treatments were made, and 2-4 true leaves at the time of intelligent weeding, because the guidance system allows the use of a more aggressive weeding device. The treatment effect on weeds was recorded 8-10 days after each treatment by counting the surviving intra-row weeds. They found that the contrast between nonintelligent and intelligent (Robovator) treatments was non-significant in terms of surviving weeds. However, in close proximity (4 $\mathrm{cm}^{2}$ zone, e.g. $2 \times 2 \mathrm{~cm}$ ) to the transplants, the Robovator does not control weeds, resulting in lower intra-row weed control than the non-intelligent tools, which could be a problem in a low competitive crop such as onion (Melander et al., 2015). The sensitivity of onion to weed competition, with onion suffering already in the first stages of development, was also reported by Hewson and Roberts (1973). The lack of weed control in the proximity of the crop has only a negligible impact on competitive crops such as cabbage, which produce quickly-expanding leaves that reach canopy closure relatively early (Melander et al., 2015).

Fennimore et al. (2014) investigated whether Robocrop improved weed control and labour efficiency in bok choy, celery, lettuce, and chicory compared to a standard inter-row cultivator, which was not able to remove weeds from the plant line. They also investigated whether Robocrop could be used to thin direct-seeded lettuce and bok choy, and they measured the cost-effectiveness of Robocrop for lettuce thinning and intra-row weed removal in celery and lettuce. Their results showed that Robocrop was generally more effective than the standard inter-row cultivator in reducing weed densities and hand-weeding times. However, Robocrop reduced seeded lettuce stands by 22 to $28 \%$ compared to handthinning and standard cultivation, resulting in lower yields and net returns. In transplanted celery, lettuce, and chicory, Robocrop removed more weeds than the standard cultivator, and reduced stands by just 6 to $9 \%$ compared to the standard cultivator. In transplanted lettuce, Robocrop was more precise, did less damage to the crop, and net returns were therefore similar to those obtained with the cultivator. In conclusion, Robocrop performed adequately in transplanted crops, but cannot be recommended in the seeded crops evaluated (Fennimore et al., 2014).

In transplanted onion and similar non-competitive row crops, intelligent weeding principles would need to be supplemented by other means to avoid the subsequent manual hand weeding into the non-treated areas (close proximity to the crop plants). In heat-tolerant non-competitive row crops (i.e., onion, garlic), a good approach would be to equip the intelligent machines with cross flaming for the entire intra-row (Martelloni et al., 2016b).

The investment cost per row for an intelligent weeder is roughly 13 times more than for example a finger weeder (Melander et al., 2015). On the other hand, the advantages are longer hours of operation (even at night time), less risk of crop injury, only one operator needed, and more flexibility in treatment timing in relation to weed growth stage (Melander et al., 2015).

Although intelligent mechanical weed control would be more suitable for weeding devices with a cutting action instead of tinebased weed removal (Rasmussen et al., 2012), it is possible to automatically regulate the inclination of tines of spring-tine harrow prototype systems based on soil conditions, weed density, and crop development (Weis et al., 2008; Rueda-Ayala et al., 2013). The crop damage may increase not only for the broadcast cultivation with the harrow, but also because the intensity with which farmers carry out harrowing tends to be constant throughout the whole field. The adjustment of the intensity in cereals is mostly based on the crop growth stage, which may also vary how selective the harrowing is. Variations in crop development, weed abundance, and a hard or a loose soil surface affect harrowing, can cause crop damage and non-uniform weed control.

A robotic spring-tine harrow was designed and built by RuedaAyala et al. (2015) for site-specific weed control in narrow row crops such as cereals. The harrow is designed to adjust the tine angle, thereby varying the harrowing intensity while cultivating the crop. The harrow uses ultrasonic sensors, which automatically control the harrowing intensity by adjusting the tine angle. The control unit commands the actuator to move and adjust the tine 
angle site-specifically according to the plant density variations, in real-time and in one operation. The system performed well at the high driving speeds needed for harrowing operations (e.g., $12 \mathrm{~km}$ $\left.\mathrm{h}^{-1}\right)$.

\section{Automated flamers}

Cross flaming can be used in crops with narrow spaces between the individual crop plants in the row, which represents the major obstacle for the use of high-tech automatic machines for mechanical weed control. Mechanical weed control is also conditioned by the soil structure, which should be easy to work with though lumpy or stony soils are common (van der Weide et al., 2008). Flame weeding is not bound by the quality of soil, although the excessive presence of lumps or stones could screen weeds from the flame.

F. Poulsen Engineering Aps. built an intra-row weeding robot that flames the weeds. The machine uses the Robovator vision system to identify crop plants (Melander et al., 2015). A series of plasma jets directed at the crop row are cycled on and off to kill weeds between crop plants. Multiple jets are used for each crop row so that there is a sufficient amount of heat to kill the weeds (Siemens, 2014).

An automatic machine for variable rate application (VRA) of flaming on maize was designed and built at the University of Pisa within the European Project Robot fleets for Highly Effective Agriculture and forestry management (RHEA). The machine was built to apply site-specific VRA of flaming in the intra row space and non-selective mechanical weed control between the crop rows. Flame weeding is applied cross to the row by a pair of burners fed with LPG. Flaming is activated automatically only when weeds are detected. The machine was coupled with an autonomous tractor equipped with an optical sensor for real-time row crop and weed detection. Specific hardware and software provide information on the weed cover percentage detected and send these data to the auto-

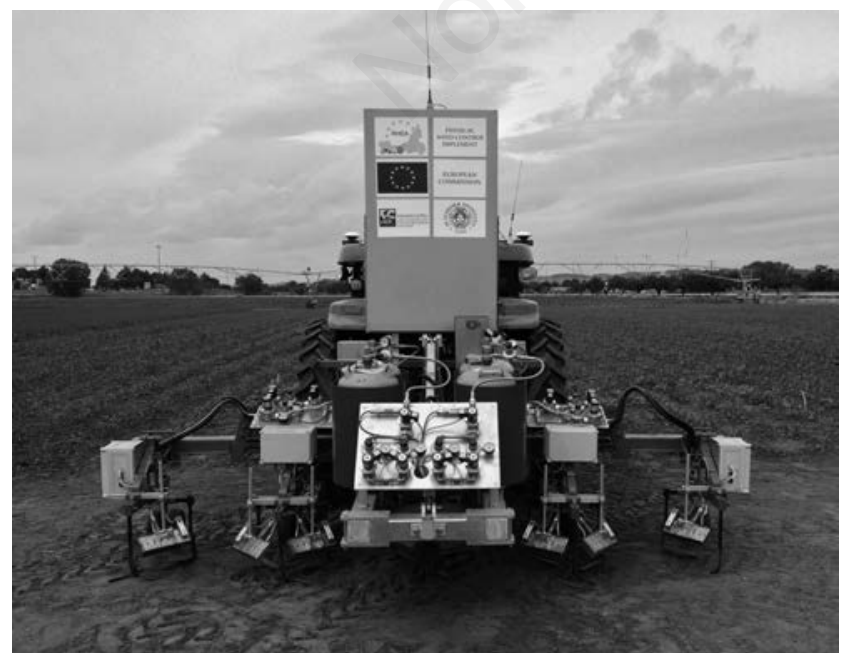

Figure 7. The automatic machine for variable rate application of flame weeding designed and built at the University of Pisa (Frasconi et al., 2014). matic machine. The LPG dose is chosen in real-time between two doses identified in the calibration phase to be effective on weed cover percentages lower or higher than $25 \%$. In the case of $0 \%$ weed cover, the burners are switched off. The ignition system of the burners was designed to be almost instantaneous in order to minimise all delays between weed detection and flaming. This avoids the use of a pilot flame, which would otherwise have to be switched on throughout the entire operation. The machine has an automatic steering system with two metallic wheels, and maintains the same trajectory as the autonomous tractor, thus avoiding accidental damage to the crop. The LPG consumption by applying VRA was $30-80 \%$ smaller than continuous flaming. LPG consumption is lower when weeds are present in patches, and higher when weeds have a regular arrangement (Figure 7) (Frasconi et al., 2014; Pérez-Ruiz et al., 2015).

\section{Conclusions}

Non-chemical technologies can control weeds without harming the environment, both in organic and conventional farming. Non-chemical weed control is crucial in minor crops such as some vegetables, where there are only few registered effective herbicides. Low-tech devices and flaming are effective for controlling weeds and are cheap, thus easily accessible also for farmers managing small/medium farms.

In Europe, high-income niche crops rarely benefit from registered herbicides, and the economic value of organic products is higher than that of conventionally grown products. These crops are often cultivated in small farms and farmers cannot invest in hightech solutions. Low-tech solutions for physical weed control are economically accessible for those farmers that need to adhere to the strict European legislation and become less dependent on herbicides.

The type of machine that can be used depends on the crop, the size of the weeds, and kind of soil, and should prevent yield losses. A low-tech and low-cost device such as an intra-row cultivator equipped with a manual guidance system could be successfully used both in small-sized low-competitive crops, characterised by high-income, and in wide row sown herbaceous crops. Flaming in the intra-row space could also be a valid alternative to mechanical tools working in the rows and could be integrated with inter-row cultivators for weed management in heat-tolerant crops. Weed harrowing can be used in narrow-row herbaceous crops. Intelligent camera-based systems capable of guiding mechanical and/or thermal weeding devices are effective but still too expensive to be transferred to small farms that still prefer to opt for low-tech and low-cost solutions.

\section{References}

Ascard J., Fogelberg F. 2008. Mechanical in-row weed control in transplanted and direct-sown bulb onions. Biol. Agric. Hortic. 25:235-51.

Ascard J., van der Weide R.Y. 2011. Thermal weed control with the focus on flame weeding. In: D.C. Cloutier, M.L. Leblanc (Eds.), Physical weed control: progress and challenges. Canadian Weed Science Society, Pinawa, Manitoba, pp 71-90.

Åstrand B., Baerveldt A.J. 2002. An agricultural mobile robot with vision-based perception for mechanical weed control. Auton. Robot. 13:21-35. 
Åstrand B., Baerveldt A.J. 2005. A vision based row-following system for agricultural field machinery. Mechatronics. 15:251-69.

Bajwa A.A., Mahajan G., Chauhan B.S. 2015. Nonconventional weed management strategies for modern agriculture. Weed Sci. 63:723-47.

Bakker T., van Asselt K., Bontsema J., Müller J., van Straten G. 2010. Systematic design of an autonomous platform for robotic weeding. J. Terramechanics. 47:63-73.

Bàrberi P. 2002. Weed management in organic agriculture: are we addressing the right issues? Weed Res. 42:177-93.

Bàrberi P., Moonen A.C., Peruzzi A., Fontanelli M., Raffaelli M. 2009. Weed suppression by soil steaming in combination with activating compounds. Weed Res. 49:55-66.

Bàrberi P., Silvestri N., Peruzzi A., Raffaelli M. 2000. Finger-harrowing of durum wheat under different tillage systems. Biol. Agric. Hortic. 17:285-303.

Bleeker P.O., van der Weide R.Y., Kurstjens D. 2002. Experiences and experiments with new in-row weeders. pp 97-100 in Proc. 5th EWRS Workshop on Physical and Cultural Weed Control, Pisa, Italy.

Bond W., Grundy, A.C. 2001. Non-chemical weed management in organic farming systems. Weed Res. 41:383-405.

Christensen S., Søgaard H.T., Kudsk, P., Nørremark M., Lund I., Nadimi E.S., Jørgensen R. 2009. Site-specific weed control technologies. Weed Res. 49:233-41.

Cirujeda A., Melander B., Rasmussen K., Rasmussen I.A. 2003. Relationship between speed, soil movement into cereal row and intra-row weed control efficacy by weed harrowing. Weed Res. 43:285-96.

Cloutier D.C., van der Weide R.Y., Peruzzi A., Leblanc M.L. 2007. Mechanical weed control. In: M.K. Upadhyaya, R.E. Blackshaw (Eds.), Non chemical weed management. Principles, concepts and technology. CAB International, UK, pp 111-134.

Costruzioni Meccaniche Ferrari. 2015. Remoweed. Available from: http://www.ferraricostruzioni.com/en/series/remoweed Accessed: November 2015.

Datta A., Knezevic S.Z. 2013. Flaming as an alternative weed control method for conventional and organic agronomic crop production system. A review. Adv. Agron. 118:399-428.

Datta A., Stepanovic S., Nedeljkovic D., Bruening C., Gogos G., Knezevic S.Z. 2013. Impact of single and repeated flaming on yield components and yield of maize. Organ. Agricult. 3:141-7.

Elsgaard L., Jørgensen M.H., Elmholt S. 2010. Effects of bandsteaming on microbial activity and abundance in organic farming soil. Agricult. Ecosyst. Environ. 137:223-30.

Fennimore S.A., Smith R.F., Tourte L., LeStrange M., Rachuy J.S. 2014. Evaluation and economics of a rotating cultivator in bok choy, celery, lattuce, and radicchio. Weed Technol. 28:176-88.

Flame Engineering, 2007. Red Dragon Liquid Torches. Flame Engineering Inc., LaCrosse, KS, USA. Available from: https://flameengineering.com/collections/agricultural-flamers Accessed: March 2017.

Fontanelli M., Frasconi C., Martelloni L., Pirchio M., Raffaelli M., Peruzzi A. 2015a. Innovative strategies and machines for physical weed control in organic and integrated vegetable crops. Chem. Engine. Trans. 44:211-6.

Fontanelli M., Martelloni L., Raffaelli M., Frasconi C., Ginanni M., Peruzzi A. 2015b. Weed management in autumn fresh market spinach: a nonchemical alternative. HortTechnol. 25:17784.

Fontanelli M., Raffaelli M., Martelloni L., Frasconi C., Ginanni M., Peruzzi A. 2013. The influence of non-living mulch, mechanical and thermal treatments on weed population and yield of rainfed freash-market tomato (Solanum lycopersicum L.). Span. J. Agric. Res. 11:593-602.

Frasconi C., Antichi D., Fontanelli M., Martelloni L., Raffaelli M., Pirchio M., Tosti G., Manfrini L., Pristeri A., Bosco S., Peruzzi A. 2016. Techniques and machines for conservation and organic agriculture: the S.M.O.C.A. Project. J. Agricult. Engine. XLVII(s1):3.

Frasconi C., Martelloni L., Fontanelli M., Raffaelli M., Emmi L., Pirchio M., Peruzzi A. 2014. Design and full realization of physical weed control (PWC) automated machine within the RHEA project. pp 3-11 in Proc. 2nd Int. Conf. on Robotics and associated High-technologies and Equipment for Agriculture and forestry (RHEA-2014), Madrid, Spain.

Freckleton R.P., Stephens P.A. 2009. Predictive models of weed population dynamics. Weed Res. 49:225-32.

Gabe S., Fried G., Kazakou E., Chauvel B., Navas M.L. 2014. Agroecological weed control using a functional approach: a review of cropping systems diversity. Agron. Sustain. Develop. 34:103-19.

Ge Z.Y., Wu W.W., Yu Y.J., Zhang R.Q. 2013. Design of mechanical arm for laser weeding robot. Appl. Mechan. Mater. 347-350:834-8.

Hansen P.K., Rasmussen, I.A., Holst N., Andreasen C. 2007. Tolerance of four spring barley (Hordeum vulgare) varieties to weed harrowing. Weed Res. 47:241-51.

Hansson D., Svensson S.E. 2007. Steaming soil in narrow bands to control weeds in row crops. p. 137 in Proc. 7th EWRS Workshop on Physical and Cultural Weed Control, Salem, Germany.

Harker K.N, O’Donovan J.T. 2013. Recent weed control, weed management, and integrated weed management. Weed Technol. 27:1-11.

Hewson R.T., Roberts H.S. 1973. Some effects of weed competition on the growth of onions. J. Hortic. Sci. 48:51-215.

Hillocks, R.J. 2012. Farming with fewer pesticides: EU pesticide review and resulting challenges for UK agriculture. Crop. Prot. 31:85-93.

Jensen R.K., Rasmussen, J. Melander B. 2004. Selectivity of weed harrowing in lupin. Weed Res. 44:245-53.

Knezevic S.Z., Evans S.P., Blankenship E.E., Van Acker R.C., Lindquist J.L., 2002. Critical period for weed control: the concept and data analysis. Weed Sci. 50:773-86.

Knezevic S.Z., Stepanovic S., Datta A., Nedeljkovic D., Tursun N., 2013. Soybean yield and yield components as influenced by the single and repeated flaming. Crop. Prot. 50:1-5.

Kurstjens D.A.G., Kropff M.J. 2001. The impact of uprooting and soil-covering on the effectiveness of weed harrowing. Weed Res. 41:211-28.

Kurstjens D.A.G., Kropff M.J., Perdok U.D. 2004. Method for predicting selective uprooting by mechanical weeders from anchorage forces. Weed Sci. 52:123-32.

Lemerle D., Gill G.S., Murphy C.E., Walker S.R., Cousens R.D., Mokhtari S., Peltzer S.J., Coleman R., Luckett D.J. 2001. Genetic improvement and agronomy for enhanced wheat competitiveness with weeds. Austr. J. Agric. Res. 52:527-48.

Lundkvist A. 2009. Effects of pre- and post-emergence weed harrowing on annual weeds in peas and spring cereals. Weed Res. 49:409-16.

Machinefabriek Steketee, BV. 2016. Steketee IC [product description]. Available from: http://www.steketee.com/product/ Steketee-IC Accessed: April 2016.

Martelloni L., Fontanelli M., Frasconi C., Raffaelli M., Peruzzi A. 2016a. Cross-flaming application for intra-row weed control in maize. Appl. Eng. Agr. 32 [In press].

Martelloni L., Frasconi C., Fontanelli M., Raffaelli M., Peruzzi A. 
2016b. Mechanical weed control on small-size dry bean and its response to cross-flaming. Span. J. Agric. Res. 14:e0203.

Marx C., Barcikowski S., Hustedt M., Haferkamp H., Rath T. 2012a. Design and application of a weed damage model for laser-based weed control. Biosyst. Eng. 113:148-57.

Marx C., Pastrana Pérez J.C., Hustedt M., Barcikowski S., Haferkamp H., Rath T. 2012b. Investigations on the absorption and the application of laser radiation for weed control. Landtechnik. 67:95-101.

Mathiassen S.K., Bak T., Christensen S., Kudsk P. 2006. The effect of laser treatments as a weed control method. Biosyst. Eng. 95:497-505.

Melander B. 1998. Interactions between soil cultivation in darkness, flaming, and brush weeding when used for in-row weed control in vegetables. Biol. Hortic. Agric. 16:1-4.

Melander B., Jørgensen M.H., Elsgaard L. 2004. Recent results in the development of band steaming fro intra-row weed control. p 154 in D.C. Cloutier, J. Ascard (Eds.), Proceedings of the $6^{\text {th }}$ EWRS (European weed research society) workshop on physical and cultural weed control, Lillehammer, Norway.

Melander, B. Kristensen J.K. 2011. Soil steaming on weed seedling emergence under the influence of soil type, soil moisture, soil structure and heat duration. Ann. Appl. Biol. 158:194-203.

Melander B., Lattanzi B., Pannacci E. 2015. Intelligent versus nonintelligent mechanical intra-row weed control in transplanted onion and cabbage. Crop Prot. 72:1-8.

Melander B., Rasmussen I.A. 2001. Effects of cultural methods and physical weed control on intrarow weed numbers, manual weeding and marketable yield in direct-sown leek and bulb onion. Weed Res. 41:491-508.

Melander B., Rasmussen I.A., Barberi P. 2005. Integrating physical and cultural methods of weed control - examples from European Research. Weed Sci. 53:369-81.

Mohler C.L. 2001. Mechanical management of weeds. In: Ecological management of agricultural weeds. Cambridge University Press, Cambridge, UK, pp 139-209.

Mojžiš M. 2002. Energetic requirements of flame weed control. Res. Agr. Eng. 48:94-97.

Mojžiš M., Varga F. 2013. Effect of setting the parameters of flame weeder on weed control effectiveness. J. Central Eur. Agric. 14:1373-80.

Nishimura A., Asai M., Shibuya T., Korokawa S., Nakamura, H. 2015. A steaming method for killing weed seeds produced in the current year under untilled conditions. Crop Prot. 71:125-31.

Nørremark M., Griepentrog H.W., Nielsen J., Søgaard H.T. 2008. The development and assessment of the accuracy of an autonomous GPS-based system for intra-row mechanical weed control in row crops. Biosyst. Eng. 101:396-410.

Nørremark M., Griepentrog H.W., Nielsen J., Søgaard H.T. 2012. Evaluation of an autonomous GPS-based system for intra-row weed control by assessing the tilled area. Precision Agr. 13:14962.

O’Dogherty M.J., Godwin R.J., Dedousis A.P., Brighton L.J., Tillet N.D. 2007. A mathematical model of the kinematics of a rotating disc for inter- and intra-row hoeing. Biosyst. Eng. 99:171-8.

Panacci E., Tei F. 2014. Effects of mechanical and chemical methods on weed control, weed seed rain and crop yield in maize, sunflower and soyabean. Crop Prot. 64:51-9.

Pérez-Ruiz M., Gonzalez-de-Santos P., Ribeiro A., FernandezQuintanilla C., Peruzzi A., Vieri M., Tomic S., Aguiera J. 2015. Highlights and preliminary results for autonomous crop protection. Comput. Electron. Agr. 110:150-61.

Pérez-Ruíz M., Slaughter D.C., Fathallah F.A., Gliever C.J., Miller
B.J. 2014. Co-robotic intra-row weed control system. Biosyst. Eng. 126:45-55.

Pérez-Ruíz M., Slaughter D.C., Gliever C.J., Upadhyaya S.K. 2012. Automatic GPS-based intra-row weed knife control system for transplanted row crops. Comput. Electron. Agr. 80:41-9.

Peruzzi A., Coultier D.C., Leblanc M.L., van der Weide R.Y. 2011a. Primary tillage. In: D.C. Cloutier, M.L. Leblanc (Eds.), Physical weed control: progress and challenges. Canadian Weed Science Society, Pinawa, Manitoba, pp 5-19.

Peruzzi A., Coultier D.C., Leblanc M.L., van der Weide R.Y. 2011b. Secondary tillage. In: D.C. Cloutier, M.L. Leblanc (Eds.), Physical weed control: progress and challenges. Canadian Weed Science Society, Pinawa, Manitoba, pp 21-34.

Peruzzi A., Ginanni M., Fontanelli M., Raffaelli M., Bàrberi P. 2007. Innovative strategies for on-farm weed management in organic carrot. Renew. Agr. Food Syst. 22:246-59.

Peruzzi A., Raffaelli M. 2000. Experimental test of selective flame weeding for different spring summer crops in central Italy. Agr. Med. 130:85-94.

Peruzzi A., Raffaelli M., Frasconi C., Fontanelli M., Bàrberi P. 2012. Influence of an injection system on the effect of activated soil steaming on Brassica juncea and the natural weed seedbank. Weed Res. 52:140-52.

Peruzzi A., Raffaelli M., Ginanni M., Fontanelli M., Frasconi C. 2011c. An innovative self-propelled machine for soil disinfection using steam and chemicals in an exothermic reaction. Biosyst. Eng. 110:434-42.

Raffaelli M., Bàrberi P., Peruzzi A., Ginanni M. 2004. Options for mechanical weed control in string bean. Agr. Med. 134:92-100.

Raffaelli M., Bàrberi P., Peruzzi A., Ginanni M. 2005. Mechanical weed control in maize: evaluation of weed harrowing and hoeing systems. Agr. Med. 135:33-43.

Raffaelli M., Fontanelli M., Frasconi C., Ginanni M., Peruzzi A. 2010. Physical weed control in protected leaf-beet in central Italy. Renew. Agr. Food Syst. 25:8-15.

Raffaelli M., Fontanelli M., Frasconi C., Ginanni M., Peruzzi A. 2011. Physical weed control in processing tomatoes in Central Italy. Renew. Agr. Food Syst. 26:95-103.

Raffaelli M., Frasconi C., Fontanelli M., Martelloni L., Peruzzi A. 2015. LPG burners for weed control. Appl. Eng. Agric. 31:71731.

Raffaelli M., Martelloni L., Frasconi C., Fontanelli M., Carlesi S., Peruzzi A. 2016. A prototype band-steaming machine: design and field application. Biosyst. Eng. 144:61-71.

Raffaelli M., Martelloni L., Frasconi C., Fontanelli M., Peruzzi A. 2013. Development of machines for flaming weed control on hard surfaces. Appl. Eng. Agric. 29:663-73.

Raffaelli M., Peruzzi A. 2002. Sviluppo di una nuova macchina per il pirodiserbo: risultati di un biennio di sperimentazione su girasole. Riv. di Ing. Agr. 2:39-46. [In Italian]

Raffaelli M., Peruzzi A., Ginanni M., Di Ciolo S. 2002. Mechanical weed control in sunflower and soyabean crops using spring-tine harrow: results of two-year trials. Agr. Med. 132:112-21.

Rasmussen I.A. 2004. The effect of sowing date, stale seedbed technique, row width and mechanical weed control on weeds and yields of organic winter wheat. Weed Res. 44:12-20.

Rasmussen J. 2003. Punch planting, flame weeding and stale seedbed for weed control in row crops. Weed Res. 43:393-403.

Rasmussen J., Bibby B.M., Schou A.P. 2008. Investigating the selectivity of weed harrowing with new methods. Weed Res. 48:52332.

Rasmussen J., Griepentrog H.W., Nielsen J., Henriksen C.B. 2012. Automated intelligent rotor tine cultivation and punch planting to 
improve the selectivity of mechanical intra-row weed control. Weed Res. 52:327-37.

Rasmussen J., Mathiasen H., Bibby B.M. 2010. Timing of post-emergence weed harrowing. Weed Res. 50: 436-46.

Rasmussen J., Svenningsen T. 1995. Selective weed harrowing in cereals. Biol. Hort. Agric. 12:29-46.

Rasmussen K., 2002. Influence of liquid manure application method on weed control in spring cereals. Weed Res. 42:287-98.

Rueda-Ayala V., Peteinatos G., Gerhards R., Andújar D. 2015. A nonchemical system for online weed control. Sensors. 15:7691-707.

Rueda-Ayala V., Weis M., Keller M., Andújar D., Gerhards R. 2013. Development and testing of a decision making based method to adjust automatically the harrowing intensity. Sensors. 13:625471.

Shaner D.L., Beckie H.J. 2013. The future for weed control and technology. Pest. Manage. Sci. 70:1329-39.

Siemens M.C. 2014. Robotic weed control. In: Proc. of the California Weed Science Society, Monterey, California, 66:76-80.

Sivesind E.C., Leblanc M.L., Cloutier D.C., Seguin P., Stewart K.A. 2012. Impact of selective flame weeding on onion yield, pungency, flavonoid concentration, and weeds. Crop. Prot. 39:45-51.

Slaughter D.C., Giles D.K., Downey D. 2008. Autonomous robotic weed control: a review. Comput. Electron. Agr. 61:63-78.

Søresens C.G., Madsen N.A., Jacobsen, B.H. 2005. Organic farming scenarios: operational analysis and costs of implementing innovative technologies. Biosyst. Eng. 91:127-37.

Tillett N.D., Hague T., Grundy A.C., Dedousis A.P. 2008. Mechanical within-row weed control for transplanted crops using computer vision. Precision Agric. 99:171-8.

Ulloa S.M., Datta A., Bruening C., Neilson B., Miller J., Gogos G., Knezevic S.Z. 2011a. Maize response to broadcast flaming at different growth stages: effects on growth, yield and yield compo- nents. Eur. J. Agron. 34:10-9.

Ulloa S.M., Datta A., Knezevic S.Z. 2011b. Growth stage influenced sorghum response to broadcast flaming: Effects on yield and its components. Agron. J. 103:7-12.

van der Schans D., Bleeker P.O., Molendijk L., Plentinger M., van der Weide R.Y., Lotz B., Bauermeister R., Total R., Baumann D.T. 2006. In: D. van der Schans and P. Bleeker (Eds.), Practical weed control in arable farming and outdoor vegetable cultivation without chemicals. Applied plant research, Wageningen, UR.

van der Weide R.Y., Bleeker P.O., Achten V.T.J.M., Lotz L.A.P, Fogelberg F., Melander B. 2008. Innovation in mechanical weed control in crop rows. Weed Res. 48:215-24.

Vangessel M.J., Schweizer E.E., Lybecker D.W., Westra P. 1995. Compatibility and efficiency of in-row cultivation for weed management in corn (Zea mays). Weed Technol. 9:754-60.

Walsh M., Newman P., Powles S.B. 2013. Targeted weed seeds incrop: a new weed control paradigm for global agriculture. Weed Technol. 27:431-6.

Weis M., Gutjahr C., Rueda-Ayala V., Gerhards R., Ritter C., Schölderle F. 2008. Precision farming for weed management: techniques. Ges. Pflanzen. 60:171-81.

Wöltjen C., Haferkamp H., Rath T., Herzog D. 2008. Plant growth depression by selective irradiation of the meristem with $\mathrm{CO}_{2}$ and diode lasers. Biosyst. Eng. 101:316-24.

Young S.L., Meyer G.E., Woldt W.E. 2014. Future directions for automated weed management in precision agriculture. In: Young S.L., Pierce F.J. (Eds.), Automation: the future of weed control in cropping systems. Springer, Dordrecht, The Netherlands.

Zhang Y., Staab E.S., Slaughter D.C., Giles D.K., Downey D. 2012. Automated weed control in organic row crops using hyperspectral species identification and thermal micro-dosing. Crop Prot. 41:96-105. 